\title{
The Similarities Between Pseudomonas paucimobilis and Allied Bacteria Derived from Analysis of Deoxyribonucleic Acids and Electrophoretic Protein Patterns
}

\author{
By R. J. OWEN ${ }^{1 *}$ AND P. J. H. JACKMAN ${ }^{2}$ \\ ${ }^{1}$ National Collection of Type Cultures, Central Public Health Laboratory, \\ London NW9 $5 H T, U . K$. \\ ${ }^{2}$ Department of Bacteriology, Institute of Dermatology, Homerton Grove, London E9 6BX, U.K.
}

(Received 10 February 1982; revised 30 April 1982)

\begin{abstract}
The chromosomal DNA was isolated and purified from 17 strains of Pseudomonas paucimobilis, and from the type or reference strains of Flavobacterium capsulatum, $F$. devorans, $F$. multivorum, 'Chromobacterium lividum', Xanthomonas campestris and seven species of Pseudomonas. The DNA base compositions ( $m o l \% \mathrm{G}+\mathrm{C}$ ) of $P$. paucimobilis strains were between 62.2 and $68.6 \%$, and typical strains had a mean value of $65.3 \pm 0.4 \mathrm{~mol} \%$, determined from thermal denaturation temperature. DNA-DNA molecular hybridization with ${ }^{3} \mathrm{H}$-labelled probe DNA from NCTC $11030 P$. paucimobilis (the type strain) indicated that the species comprised a core of 13 closely related strains ( 74 to $96 \%$ ), which included $F$. devorans NCIB 8195 (= ATCC 10829). Four $P$. paucimobilis strains displayed lower levels of hybridization $(\leqslant 38 \%)$. The hybridization results showed that $P$. paucimobilis was not closely related to allied yellow-pigmented bacteria or to other reference pseudomonads. The electrophoretic protein patterns of representative strains were analysed by computer-assisted techniques and similarity coefficients were calculated. A high degree of congruence was obtained with the DNA hybridization data, and the protein analyses indicated that the four atypical $P$. paucimobilis strains were heterogeneous and not a single group within the species. The generic affinities of $P$. paucimobilis, $F$. capsulatum, ' $P$. azotocolligans' and $P$. echinoides are uncertain, but available chemotaxonomic data indicate these species could provide the basis for a new genus.
\end{abstract}

\section{INTRODUCTION}

Holmes et al. (1977) proposed the name Pseudomonas paucimobilis for certain yellowpigmented, Gram-negative, rod-shaped bacteria isolated from clinical sources and from the hospital environment. The species corresponded to a group of bacteria previously known as Group IIk, biotype 1 (Tatum et al., 1974). Clinical bacteriologists sometimes refer to strains of Group IIk, biotype 1 as 'xanthomonad' or 'Xanthomonas-like', and Holmes et al. (1977) showed by a numerical analysis of phenotypic data that $P$. paucimobilis was more similar to species of Xanthomonas than to representatives of authentic Pseudomonas species. Even so, Holmes et al. (1977) found that the species differed from Xanthomonas in several important biochemical tests, notably in producing cytochrome oxidase. Additional evidence to exclude $P$, paucimobilis from Xanthomonas was subsequently obtained by Jenkins et al. (1979), who identified the main pigment of $P$. paucimobilis as a carotenoid (nostoxanthin), a different compound from the brominated aryl-polyenes present in Xanthomonas species.

Subsequent to the Holmes et al. (1977) proposal of the name $P$. paucimobilis, several cases of infections or colonization in man have been attributed to the species (Hajiroussou et al., 1979; Peel et al., 1979; Slotnick et al., 1979; Crane et al., 1981), and evidence has been found of similarities between it and various other species in the Flavobacterium-Cytophaga complex. Yabuuchi et al. (1979) reported that Flavobacterium devorans ATCC 10829 and P. paucimobilis 
were identical to each other in a comprehensive range of biochemical characteristics, DNA base compositions and cellular fatty acid compositions. Oyaizu \& Komagata (1981) using similar techniques also found a close relationship between the above two species and with $F$. capsulatum. Furthermore, Jenkins et al. (1979) identified nostoxanthin as the major pigment of $P$. echinoides and ' $P$. azotocolligans', a fact they suggested might indicate taxonomic affinities to $P$. paucimobilis. In a study of rRNA cistron similarities amongst flavobacteria, Bauwens $\&$ De Ley (1981) found that $P$. paucimobilis grouped with $F$. capsulatum, $F$. devorans, 'P. azotocolligans' and 'Chromobacterium folium', which provided further evidence that the species was not typical of the genus Pseudomonas. The strains previously known as Group IIk, biotype 2 (Tatum et al., 1974), which resembled $P$. paucimobilis in phenotypic characteristics, were named $F$. multivorum (Holmes et al., 1981). The new species differed from $P$. paucimobilis both in its DNA base composition (Holmes et al., 1977) and in its cellular fatty acid composition (Dees et al., 1979).

The aim of the present study was to examine the relationships within $P$. paucimobilis, as well as its relationships to other species of yellow-pigmented bacteria for which there is evidence of possible affinities. Determinations of DNA base compositions and DNA-DNA molecular hybridization ( $\mathrm{S} 1$ endonuclease assay) were used to investigate strains. As there is evidence (Kersters \& De Ley, 1980) that relationships between bacteria based on the numerical analysis of whole cell protein electrophoretic patterns agree well with DNA hybridization data, selected strains were examined to determine the extent of correlation between these two taxonomic approaches.

\section{METHODS}

Strains used and growth conditions. The bacterial strains used and their sources are listed in Table 1. Strain numbers prefixed with 'A', 'F', or 'CL' were previously received by the NCTC for identification and the name given here is the result of that identification. The names of the other strains are the designations with which they were received from the respective culture collections. The names in quotation marks are not on the Approved Lists of Bacterial Names (Skerman et al., 1980) and have no standing in nomenclature. Full details of the sources, phenotypic characteristics and clinical significance of the strains of $P$. paucimobilis have been published previously (Holmes et al., 1977; Hajiroussou et al., 1979; Peel et al., 1979; Slotnick et al., 1979). The bacteria, except $P$. echinoides, were grown overnight at $30^{\circ} \mathrm{C}$ in $200 \mathrm{ml}$ nutrient broth (Oxoid no. 2) with aeration in an orbital incubator at 120 r.p.m., or on nutrient agar [Oxoid no. 2 nutrient broth and $1 \cdot 2 \%(\mathrm{w} / \mathrm{v})$ agar] in plastic Petri dishes. Pseudomonas echinoides ICPB 2835 was grown at $30^{\circ} \mathrm{C}$ for $2 \mathrm{~d}$ on a medium which contained $5 \%(w / v)$ Bacto cystine agar (Difco) and $1 \%(w / v)$ Bacto haemoglobin (Difco). Bacteriological purity of the cultures was rigorously checked by subculture on nutrient agar and by microscopic examination of Gram-stained cells. Conventional biochemical characteristics were examined previously (Holmes et al., 1977; B. Holmes, personal communication).

Isolation and purification of DNA. The bacteria were harvested, washed and suspended in $0 \cdot 15 \mathrm{M}-\mathrm{NaCl} / 0 \cdot 1 \mathrm{M}-$ EDTA buffer pH 8.0 and the DNA was isolated and purified as described previously (Owen \& Holmes, 1978, 1980). In the preparation of labelled DNA, the bacteria were grown in the medium described by Owen \& Snell (1976) which contained: $10 \mathrm{ml} \mathrm{M9}$ salts solution (prepared at tenfold concentration; $\mathrm{Na}_{2} \mathrm{HPO}_{4}, 60 \mathrm{~g} ; \mathrm{KH}_{2} \mathrm{PO}_{4}$,

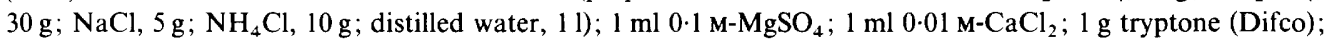
$2.5 \mathrm{ml} 40 \%(\mathrm{w} / \mathrm{v})$ maltose and $20 \mu \mathrm{g}$ thiamin (both sterilized separately by filtration); $85 \mathrm{ml}$ distilled water. The bacteria were grown overnight at $37^{\circ} \mathrm{C}$ in $5 \mathrm{ml}$ medium, subcultured into $10 \mathrm{ml}$ of fresh medium, and then incubated at $37^{\circ} \mathrm{C}$ with aeration. After 2 to $3 \mathrm{~h},\left[{ }^{3} \mathrm{H}\right]$ thymidine (Amersham) was added $\left[10 \mu \mathrm{Ciml} l^{-1}\right.$ $\left.\left(370 \mathrm{kBq} \mathrm{ml}^{-1}\right)\right]$, followed by two further additions $\left(5 \mu \mathrm{Ci} \mathrm{ml}^{-1}\right)$ at $1 \mathrm{~h}$ intervals, and the incubation continued for about $5 \mathrm{~h}$. The cells were collected by centrifugation and suspended in about $1 \mathrm{ml} \mathrm{NaCl} /$ EDTA buffer. The cells were lysed and the DNA was extracted as described previously (Owen et al., 1978), except that the aqueous phase containing the nucleic acids separated after the phenol/chloroform deproteinization was purified by gel filtration chromatography. A column $(30 \times 1.8 \mathrm{~cm}$; Pharmacia) packed with Sepharose 4B (Pharmacia) was washed and equilibrated with $0.0168 \mathrm{M}-\mathrm{NaCl}$. After loading with the aqueous supernatant $(1.5 \mathrm{ml})$, the column was eluted at a flow rate of $1 \mathrm{ml} \mathrm{min}^{-1}$ and $0.2 \mathrm{ml}$ fractions were collected. Elution was monitored continuously at $254 \mathrm{~nm}$ by a UV optical unit and flow cell (LKB Uvicord type 470 lA). The fractions that contained ${ }^{3} \mathrm{H}$-labelled DNA were identified by their radioactivity and pooled. The concentration of double-stranded DNA was estimated assuming an $A_{260}$ of $1=50 \mu \mathrm{g}$ DNA ml-1. The DNA solutions were considered to be sufficiently purified if the absorbance ratios $230 / 260$ and $280 / 260(\mathrm{~nm})$ were about $0 \cdot 450$ and $0 \cdot 515$, respectively. The DNA solutions for hybridization were stored at $-30^{\circ} \mathrm{C}$.

Thermal denaturation. The DNA base composition $(\mathrm{mol} \% \mathrm{G}+\mathrm{C})$ was estimated from the thermal denaturation temperature $\left(T_{m}\right)$, which was determined in a spectrophotometer (Owen et al., 1978) by the method of Marmur \& 
Table 1. Bacterial strains used and sources

Received as:

Name
Pseudomonas paucimobilis
P. paucimobilis
P. paucimobilis
P. paucimobilis
P. paucimobilis
P. paucimobilis
P. paucimobilis
P. paucimobilis
P. paucimobilis
P. paucimobilis
P. paucimobilis
P. paucimobilis
P. paucimobilis
P. paucimobilis
P. paucimobilis
P. paucimobilis
P. paucimobilis
P. paucimobilis
P. paucimobilis
P. aeruginosa
'P. azotocolligans'
P. cepacia
P. echinoides
$P$. flava
P. maltophilia
P. putida
'Chromobacterium lividum'
F. capsulatum
F. devorans
F. multivorum
Xanthomonas campestris

Obtained
from:*

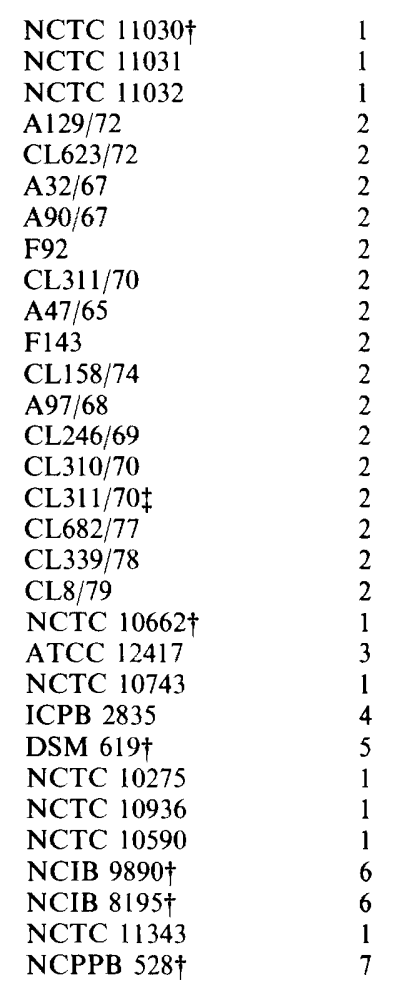

Source of isolation

Hospital environmental, U.K.

Human, U.S.A.

Human, U.S.A.

Human, U.K.

Human, U.K.

Hospital environmental, U.K.

Hospital environmental, F.R.G.

Human, U.K.

Hospital environmental, U.K.

Hospital, U.K.

Human, U.K.

Hospital environmental, U.K.

Environmental, U.K.

Hospital environmental, U.K.

Human, U.K.

Human, U.K.

Human, Australia

Human, U.K.

Human, U.S.A.

Human, U.K.

Soil, U.S.A.

Onion, U.S.A.

Plate contaminant, F.R.G.

Ditch mud, Holland

Human oral cavity, U.S.A.

Source not known

Plant material, U.K.

Environmental, U.S.A.

Environmental, U.S.A.

Human, U.S.A.

Source not known

* 1, National Collection of Type Cultures (NCTC), London, U.K.; 2, field isolate previously received by NCTC for identification; 3, American Type Culture Collection (ATCC) Rockville, Md., U.S.A.; 4, International Collection of Phytopathogenic Bacteria (ICPB), University of California, Davis, U.S.A.; 5, Deutsche Sammlung von Mikroorganismen (DSM), Göttingen, F.R.G.; 6, National Collection of Industrial Bacteria (NCIB), Aberdeen, U.K.; 7, National Collection of Plant Pathogenic Bacteria (NCPPB), Harpenden, U.K.

† Type strain (Skerman et al., 1980).

‡ Strain examined by protein electrophoresis only.

Doty (1962). The mol $\% \mathrm{G}+\mathrm{C}$ was calculated from the $T_{m}$ determined in $0 \cdot 1 \times \mathrm{SSC}$ buffer $(0 \cdot 15 \mathrm{M}-\mathrm{NaCl}$ buffered with $0.015 \mathrm{M}$-trisodium citrate $\mathrm{pH} 7 \cdot 0)$ using the equation: $\% \mathrm{G}+\mathrm{C}=52 \cdot 0+2 \cdot 08\left(T_{m x}-75 \cdot 3\right)$, where $T_{m x}$ is the denaturation temperature of the test DNA, and $75 \cdot 3{ }^{\circ} \mathrm{C}$ is the denaturation temperature of reference DNA from Escherichia coli NCTC 10537.

Fragmentation of double-stranded DNA. The DNA concentration was adjusted to $70 \mu \mathrm{g} \mathrm{ml}^{-1}$ and sheared by sonication as described previously (Owen et al., 1978).

DNA-DNA molecular hybridization. ${ }^{3} \mathrm{H}$-labelled DNA $(1 \mu \mathrm{g})$ was mixed with unlabelled DNA $(50-100 \mu \mathrm{g})$ in $0.3 \mathrm{ml}$ Pierce Reactivials, and heat denatured at $90^{\circ} \mathrm{C}$ for $10 \mathrm{~min}$, then immediately cooled to near $0{ }^{\circ} \mathrm{C}$ in an ice bath. The $\mathrm{Na}^{+}$concentration of the DNA solution was adjusted to $0.42 \mathrm{M}$ in a final volume of $200 \mu \mathrm{l}$ by adding $10 \mu \mathrm{l}$ $4.2 \mathrm{M}-\mathrm{NaCl}$. Each DNA mixture was incubated overnight (approximately $18 \mathrm{~h}$ ) at $70^{\circ} \mathrm{C}$ (this temperature corresponds to $T_{m}-26^{\circ} \mathrm{C}$ ) to give homologous reassociations of at least $90 \%$. The amount of double-stranded DNA present in the reaction mixture was determined by the S1 endonuclease assay of Crosa et al. (1973) with slight modifications. After incubation, $200 \mu \mathrm{l}$ enzyme assay buffer $(0.062 \mathrm{M}$-sodium acetate buffer $\mathrm{pH} 4 \cdot 8$, and $2.05 \mathrm{~mm}$-zinc sulphate), $20 \mu \mathrm{g}$ sheared, denatured calf-thymus DNA ml-1 (stock solution contains: $2 \mathrm{mg}$ DNA $\mathrm{ml}^{-1}$ in $10 \mathrm{mM}$-Tris/ $\mathrm{HCl}$ buffer $\mathrm{pH} 7 \cdot 5$ ), and 50 units SI endonuclease (Sigma) were added and thoroughly mixed. A zero-time sample $(50 \mu \mathrm{l})$ was removed and the mixture was incubated for $20 \mathrm{~min}$ at $60^{\circ} \mathrm{C}$. The reaction was stopped by chilling in an ice bath, and $70 \mu \mathrm{l}$ samples were placed on dry $2.4 \mathrm{~cm}$ DE 81 filter discs (Whatman) in a scintillation vial. Each disc was washed in triplicate with $5 \mathrm{ml}$ volumes of $5 \%(\mathrm{w} / \mathrm{v}) \mathrm{Na}_{2} \mathrm{HPO}_{4}($ Salzberg et al., 
1977; Popoff \& Coynault, 1980), and in duplicate with $5 \mathrm{ml}$ volumes of distilled water. Discs were dried thoroughly and radioactivity was determined in a scintillation counter as described previously (Owen \& Snell, 1976).

Calculation of percentage DNA hybridization. At least four determinations were made for each DNA pair hybridized. Each set of hybridizations included a positive control (the labelled DNA with its corresponding unlabelled DNA), and a negative control [the labelled DNA with an unrelated unlabelled DNA from Brevibacterium sp. NCDO 2051 with a $\mathrm{G}+\mathrm{C}$ content of $66 \%$ (D. Pitcher, personal communication)]. The reassociation of the label with itself was about $5 \%$. Relative hybridization of heterologous strands of DNA, corrected for self-reassociation of the labelled DNA, was expressed as a percentage hybridization, with the reassociation of homologous strands at $100 \%$.

Preparation of protein samples. Approximately $0.5 \mathrm{~g}$ wet weight of the bacteria were harvested, washed and suspended in $1 \mathrm{ml}$ of electrophoresis buffer $(0.09 \mathrm{M}$-Tris/ $\mathrm{HCl}, 0.08 \mathrm{M}$-boric acid, $0.0025 \mathrm{M}$-EDTA, pH $8 \cdot 35)$. The bacteria were disrupted by sonication (MSE Instruments ultra-sonicator) for $2 \mathrm{~min}$ in an ice bath. The sonicate was centrifuged at $4{ }^{\circ} \mathrm{C}$ for $30 \mathrm{~min}$ at $36000 \mathrm{~g}$ and the supernatant was then centrifuged for a further $2 \mathrm{~h}$ at $36000 \mathrm{~g}$. The concentration of protein in the supernatant was determined by the Lowry method. The protein samples were stored at $-20^{\circ} \mathrm{C}$.

Electrophoresis. Protein samples containing approximately $200 \mu \mathrm{g}$ of protein were layered on to gels containing a gradient of 2.7 to $27 \%(\mathrm{w} / \mathrm{v})$ polyacrylamide (Gradipore gels, Universal Scientific, London). The gels measured $120 \times 70 \times 0.3 \mathrm{~mm}$ and were cast in batches of 100 . Thyroglobulin (Sigma; $10 \mu \mathrm{g}$ ) was added as a marker to each well. Electrophoresis was performed in a water-cooled tank (Pharmacia GE4 II) for $20 \mathrm{~h}$ at a constant voltage of $100 \mathrm{~V}$ at $15^{\circ} \mathrm{C}$. After electrophoresis, the gels were stained in $0.04 \%$ (w/v) Coomassie brilliant blue G250 (Sigma) in $3.5 \%(\mathrm{w} / \mathrm{v})$ perchloric acid for $16 \mathrm{~h}$ and then destained in distilled water.

Scanning of gels. The stained protein patterns in the gels were scanned with a densitometer (Vitatron TLD 100; MSE Iristruments) under the following conditions : slit width $250 \mu \mathrm{m}$, red filter 603 and scanning speed $1 \mathrm{~mm} \mathrm{~s}^{-1}$. The complete scan, which included the thyroglobulin band, comprised 500 absorbance values ( $Y$ values) recorded at $0.2 \mathrm{~mm}$ intervals along the gel. The $Y$ values were recorded as integers between 1 and 255 using an analogue to digital converter (Millhouse Designs, Alton, Hampshire) interfaced to a microcomputer (Commodore PET 3032) and finally stored on magnetic disk (Commodore 3040). The trace used for computations was started 5 points $(1 \mathrm{~mm})$ from the centre of the thyroglobulin band, which was the highest $Y$ value in the first 30 points $(6 \mathrm{~mm})$ of the scan, and consisted of the next 400 points $(80 \mathrm{~mm})$. This original trace was then reduced to a 100 point trace by averaging the points in groups of four in order to shorten the time required for computing. The gels were routinely scanned at high resolution in case the data were needed for future analysis. A general background trend in each trace was removed to increase the discrimination between protein patterns. A grossly averaged trace of 10 points (the 100 point trace averaged in groups of ten) was constructed and a fraction $(0 \cdot 8)$ of this trace was then subtracted from the 100 point trace. The mathematical treatment of the background trend is dealt with elsewhere (Jackman, 1981).

Computations. The best fit between each pair of traces with background trends removed was computed and similarities were calculated using the Pearson product moment correlation coefficient $(r)$ herein referred to as the correlation coefficient. Strains were then clustered by the method of unweighted pair-group average linkage (UPGMA). Details of the methods are given by Sneath \& Sokal (1973). The best fit between each pair of traces was obtained by laterally shifting one trace with respect to the other in singie point steps of \pm 5 points either side of the initial alignment with respect to the thyroglobulin band. The correlation coefficient was calculated at each point and the highest value was used in the cluster analysis. All calculations were performed on a Commodore PET 3032 using programs written by and available from P. J. H. Jackson.

\section{RESULTS}

\section{DNA characteristics}

The thermal denaturation temperatures and the corresponding base compositions (mol \% $\mathrm{G}+\mathrm{C}$ ) of 17 strains previously identified on phenotypic characteristics as $P$. paucimobilis are listed in Table 2. Fifteen strains had G $+\mathrm{C}$ contents of 64.9 to $65.9 \mathrm{~mol} \%$ with a mean and standard deviation of $65.3 \pm 0.4 \mathrm{~mol} \%$. Strains CL8/79 and A97/68 had slightly higher values of $66.4 \%$ and $67.4 \%$, respectively. The majority of the strains gave high levels $(\geqslant 74 \%)$ of hybridization with labelled DNA from NCTC 11030 as shown in Table 2. Four strains were atypical in having lower $(\leq 38 \%)$ hybridization levels with NCTC 11030 ; three of these (NCTC 11032, CL158/74 and CL8/79) had DNA hybridization levels between 34 and $38 \%$. The remaining strain (A97/68) was $10 \%$ related to NCTC 11030.

Table 2 also lists the DNA characteristics of the various strains allied to $P$. paucimobilis and the selected reference strains. Flavobacterium devorans NCIB 8195 was identical to the typical 
Table 2. DNA characteristics and protein similarities of P. paucimobilis and allied bacteria

\begin{tabular}{|c|c|c|c|c|c|}
\hline \multirow[b]{2}{*}{$\begin{array}{l}\text { Reference no. } \\
\text { in Fig. } 1\end{array}$} & \multirow[b]{2}{*}{ Strain } & \multirow[b]{2}{*}{$\begin{array}{c}T_{m} \\
\left({ }^{\circ} \mathrm{C}\right)^{*}\end{array}$} & \multirow[b]{2}{*}{$\begin{array}{c}\mathrm{G}+\mathrm{C} \text { content } \\
(\mathrm{mol} \%)^{\dagger}\end{array}$} & \multicolumn{2}{|c|}{ NCTC 11030 reference strain } \\
\hline & & & & $\begin{array}{c}\text { DNA-DNA } \\
\text { hybridization } \\
(\%)_{\ddagger}^{\ddagger}\end{array}$ & $\begin{array}{c}\text { Protein } \\
\text { pattern } \\
\text { similarity }(\%) \S\end{array}$ \\
\hline 1 & P. paucimobilis NCTC & & & & \\
\hline & 11030 & $N D \|$ & $65 \cdot 5$ & $(100)$ & 90 \\
\hline 2 & P. paucimobilis CL339/78 & $81.55 \pm 0.05$ & $65 \cdot 0$ & $96 \pm 4$ & 82 \\
\hline 3 & P. paucimobilis CL682/77 & $81.7 \pm 0.00$ & $65 \cdot 3$ & $95 \pm 3$ & 76 \\
\hline 4 & P. paucimobilis A90/67 & $81.8 \pm 0.00$ & $65 \cdot 5$ & $95 \pm 1$ & 76 \\
\hline 5 & P. paucimobilis CL623/72 & $81 \cdot 65 \pm 0.15$ & $65 \cdot 2$ & $86 \pm 8$ & 71 \\
\hline 6 & P. paucimobilis A $47 / 65$ & $81 \cdot 6 \pm 0 \cdot 10$ & $65 \cdot 1$ & $85 \pm 3$ & 62 \\
\hline 7 & P. paucimobilis $\mathrm{F} 143$ & $81.55 \pm 0.05$ & $65 \cdot 0$ & $83 \pm 6$ & 78 \\
\hline 8 & P. paucimobilis CL $310 / 70$ & ND'| & $64 \cdot 9^{a}$ & $83 \pm 1$ & ND \\
\hline 9 & P. paucimobilis CL246/69 & $81.95 \pm 0.05$ & $65 \cdot 8$ & $82 \pm 4$ & 74 \\
\hline 10 & P. paucimobilis $\mathrm{F} 92$ & $81 \cdot 8 \pm 0.10$ & $65 \cdot 5$ & $81 \pm 7$ & ND \\
\hline 11 & P. paucimobilis A129/72 & $81.95 \pm 0.05$ & $65 \cdot 8$ & $80 \pm 1$ & ND \\
\hline 12 & P. paucimobilis A $32 / 67$ & $81.75 \pm 0.15$ & $65 \cdot 4$ & $78 \pm 1$ & ND \\
\hline 13 & $P$ paucimobilis NCTC & & & & \\
\hline & 11031 & $\mathrm{ND}$ & $64 \cdot 9^{a}$ & $74 \pm 2$ & 80 \\
\hline 14 & P. paucimobilis NCTC & & & & \\
\hline & 11032 & ND $\|$ & $64 \cdot 9^{a}$ & $38 \pm 6$ & 46 \\
\hline 15 & P. paucimobilis CL158/74 & $82 \cdot 0 \pm 0 \cdot 10$ & $65 \cdot 9$ & $35 \pm 3$ & 55 \\
\hline 16 & P. paucimobilis CL8/79 & $82 \cdot 2 \pm 0 \cdot 10$ & $66 \cdot 4$ & $34 \pm 1$ & 42 \\
\hline 17 & P. paucimobilis A97/68 & ND $\|$ & $67 \cdot 4^{a}$ & $10 \pm 0$ & 38 \\
\hline 18 & F. devorans NCIB 8195 & $81.65 \pm 0.15$ & $65 \cdot 2$ & $93 \pm 6$ & 87 \\
\hline 19 & F. capsulatum NCIB 9890 & $81 \cdot 6 \pm 0.10$ & $65 \cdot 1$ & $8 \pm 3$ & ND \\
\hline 20 & 'P. azotocolligans' ATCC & & & & \\
\hline & 12417 & $82.25 \pm 0.15$ & $66 \cdot 6$ & $12 \pm 2$ & 40 \\
\hline 21 & P. flava DSM 619 & $83.3 \pm 0.10$ & $68 \cdot 6$ & $\overline{0}$ & ND \\
\hline 22 & P. echinoides ICPB 2835 & $81.95 \pm 0.25$ & $65 \cdot 8$ & 12 & ND \\
\hline 23 & $X$. campestris NCPPB 528 & $81.5 \pm 0.10$ & $64 \cdot 9$ & 0 & ND \\
\hline 24 & 'C. lividum' NCTC 10590 & $\overline{\mathrm{ND}}$ & $61 \cdot 0^{b}$ & $10 \pm 3$ & ND \\
\hline 25 & P. cepacia NCTC 10743 & ND & $67 \cdot 5^{c}$ & $\overline{0}$ & ND \\
\hline 26 & $P$. putida NCTC 10936 & $80.25 \pm 0.05$ & $62 \cdot 2$ & $5 \pm 1$ & ND \\
\hline 27 & P. maltophilia NCTC 10257 & ND & $65 \cdot 0^{c}$ & $4 \pm 3$ & ND \\
\hline 28 & F. multivorum NCTC 11343 & ND & $38 \cdot 2^{d}$ & $2 \pm 2$ & ND \\
\hline 29 & P. aeruginosa NCTC 10662 & ND & $66 \cdot 8^{c}$ & 0 & ND \\
\hline
\end{tabular}

ND, Not determined.

* Values for mean $T_{m}$ are averages of two or three separate determinations + S.D. in $0 \cdot 1 \times$ SSC buffer.

+ Values not determined in this study are marked by superscript letters: $a$, recalculated (as described in Methods) from $T_{m}$ data of Holmes et al. (1977); $b$, from Gillis \& De Ley (1980); $c$, from De Ley et $a l$. (1978); $d$, from Holmes et al. (1981).

\# Mean value of at least two determinations in most cases. Pooled S.D. $= \pm 3 \%(n=23)$.

$\S$ Average similarity was calculated relative to the duplicates of the reference strain.

These values were reported by Holmes et al. (1977).

strains of $P$. paucimobilis in its DNA base composition and level of molecular hybridization. The other strains of yellow-pigmented bacteria had similar base compositions to $P$. paucimobilis, except for ' $C$. lividum' NCTC 10590 which had a slightly lower value of $61 \%$ (Gillis \& De Ley, 1980), and F. multivorum NCTC 11343 (previously CDC Group IIk, biotype 2) with a much lower value of $38.2 \%$; the latter species therefore could not share any common DNA with $P$. paucimobilis. The DNA-DNA hybridization results showed that all these species had low $(\leqslant 12 \%)$ hybridization levels with the type strain of $P$. paucimobilis. The DNA results are summarized in Fig. 1.

\section{Electrophoretic analysis of proteins}

Electrophoresis in gradient gels resolved the cellular proteins of each of 18 investigated strains of $P$. paucimobilis and allied species into about 50 bands with molecular masses in the 


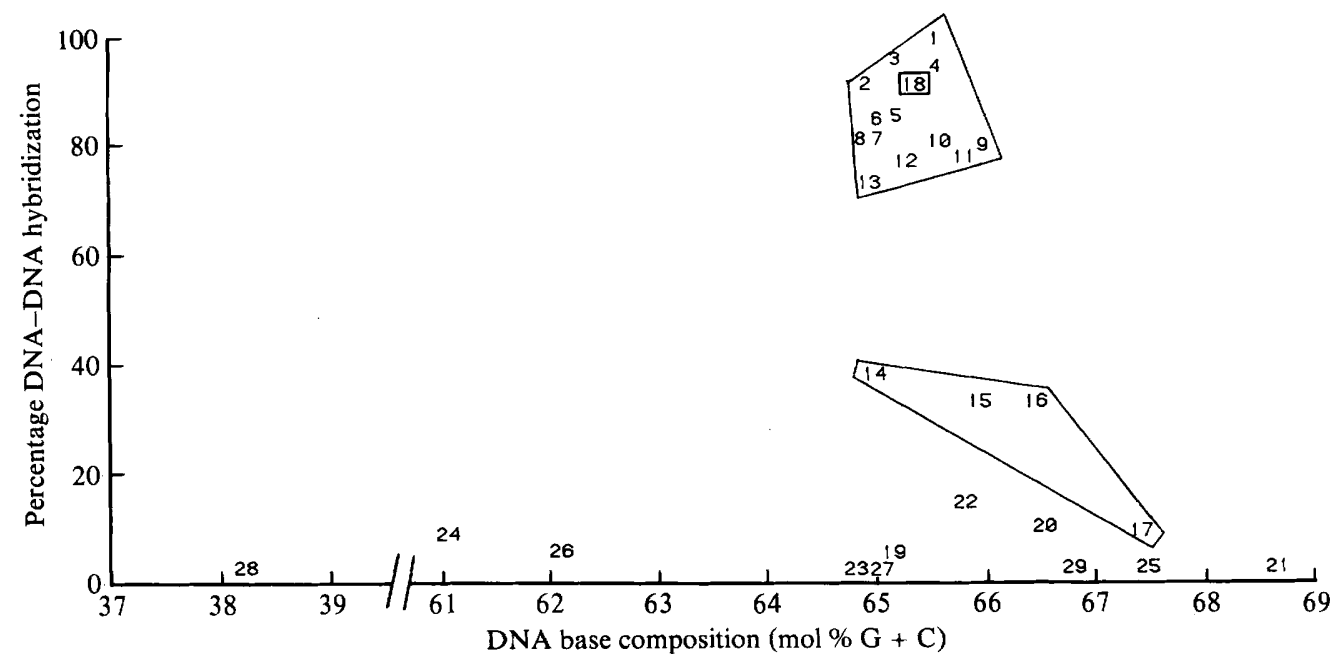

Fig. 1. Overall DNA similarities (hybridizations and $\mathrm{G}+\mathrm{C}$ contents) between Pseudomonas paucimobilis NCTC 11030 , the type and DNA reference strain (reference no. 1) and other strains of $P$. paucimobilis (reference nos 2-17, Table 2) and allied bacteria (reference nos 18-29, Table 2). The shapes and areas outlined are not intended to have a precise taxonomic significance.
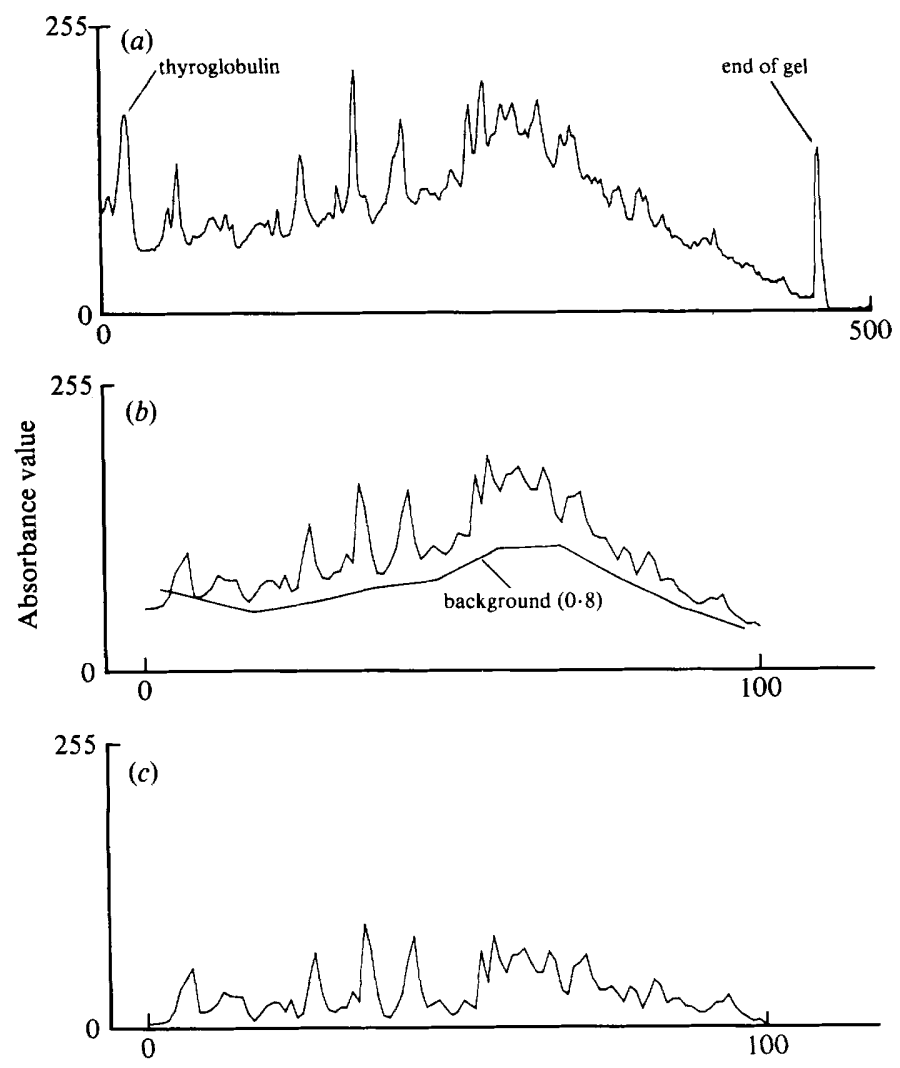

Fig. 2. Densitometric traces of the electrophoretic protein pattern of P. paucimobilis NCTC 11030. $(a)$ Complete trace (500 points); $(b)$ reduced trace (100 points); $(c)$ final trace (background removed). Details of the computation of the traces are given in Methods. 

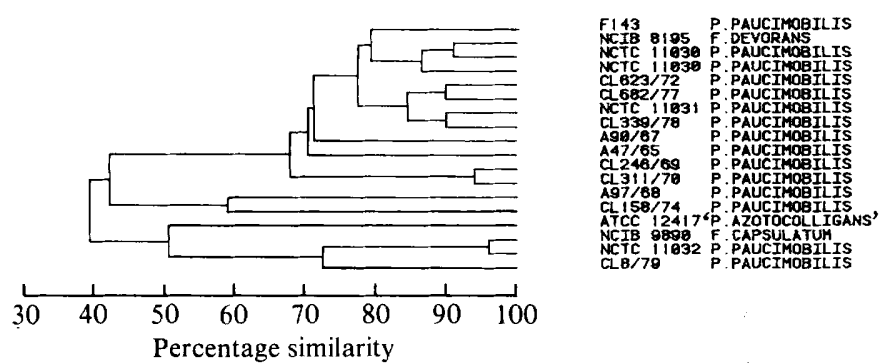

Fig. 3. Dendrogram based on protein patterns using the correlation coefficient with 0.8 background subtracted and UPGMA clustering.

range $12-500 \mathrm{kDal}$. Figure 2 shows the original (500 point) densitometric trace of the electrophoretic protein pattern of $P$. paucimobilis NCTC 11030 , as well as the grossly averaged trace with and without the background. Duplicate samples of NCTC 11030 were run on two different gels and shows $90 \%$ similarity, which is a measure of the reproducibility of the method.

The dendrogram derived from the numerical analysis based on the protein patterns of 17 strains is shown in Fig. 3. Eleven strains formed a cluster with similarities of $68 \%$ or above. These strains included P. paucimobilis NCTC 11030 (the type strain), 10 other strains identified on phenotypic characteristics as $P$. paucimobilis, and $F$. devorans NCIB 8195 . The remaining six strains joined the main $P$. paucimobilis cluster at similarity levels below $42 \%$, and included four strains identified on phenotypic characteristics as $P$. paucimobilis, ' $P$. azotocolligans' and $F$. capsulatum. Table 2 lists the percentage similarity derived from the electrophoretic protein patterns between $P$. paucimobilis and other strains.

\section{DISCUSSION}

The results on $\mathrm{G}+\mathrm{C}$ contents and DNA-DNA hybridization, and the electrophoretic analysis of cellular proteins provided evidence that $P$. paucimobilis, as currently defined on conventional morphological and biochemical characteristics (Holmes et al., 1977), contains a core of highly related strains. Furthermore, the results obtained with $F$. devorans NCIB 8195 (=ATCC 10829) confirm the studies of Yabuuchi et al. (1979) in showing the strain to be almost identical to the type strain of $P$. paucimobilis. It is also clear from the results that $P$. paucimobilis contains some atypical strains with slightly different base sequences and protein profiles. Pseudomonas paucimobilis A97/68 is possibly incorrectly identified as it has low DNA similarity to the type strain. Likewise, low DNA similarity levels were found between $P$. paucimobilis and phenotypically allied species producing yellow pigments such as 'P. azotocolligans', $F$. capsulatum, $P$. echinoides and $P$. flava.

Figure 4 shows that the similarities within and between $P$. paucimobilis and allied bacteria, derived from DNA hybridization and electrophoretic analysis of cellular proteins, had a high degree of congruence $(r=0.92)$. The overall results obtained thus agreed with the observation of Kersters \& De Ley (1980) that strains with high DNA similarity tend to have similar protein patterns. It is generally accepted that bacteria with high levels $(\geqslant 70 \%)$ of DNA base similarity relative to a particular reference DNA, must also show DNA similarities to each other, and that is supported by the electrophoresis results. In the case of strains with lower DNA relatedness, no such assumption can be made. However, it was evident from the protein analysis that $P$. paucimobilis NCTC 11032 and CL8/79 were related. It is likely, therefore, that the two strains also have similar DNA base sequences to each other. Furthermore, both were $36 \pm 2 \%$ related to NCTC 11030. The three remaining strains, $P$. paucimobilis A97/68 and CL158/74, and ' $P$. azotocolligans' ATCC 12417, were not in general closely related in their proteins either to each other or to $P$. paucimobilis. The above four atypical $P$. paucimobilis strains did not show any consistent phenotypic differences from other members of the species (Holmes et al., 1977), so 


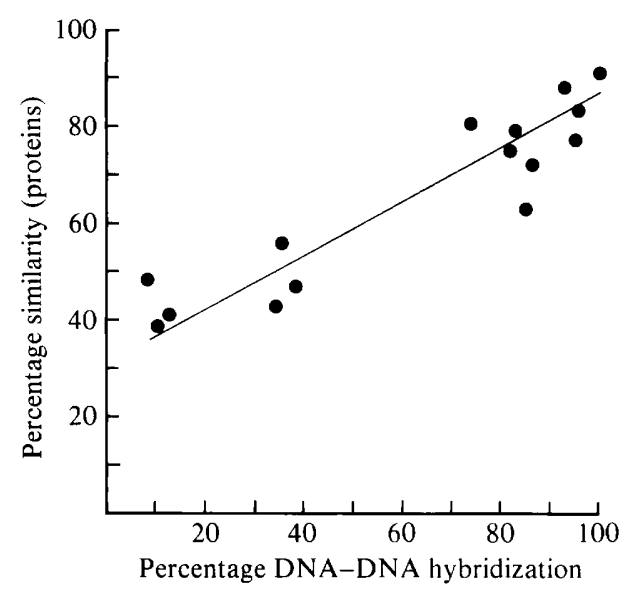

Fig. 4. Correlation of percentage protein similarity with percentage DNA-DNA hybridization.

their reclassification is not advocated at present. Likewise, ' $P$. azotocolligans' was phenotypically similar to $P$. paucimobilis (R. J. Owen, unpublished results). In contrast, the DNA differences shown by $P$. echinoides, $P$. flava and $F$. capsulatum were reflected in phenotypic differences (Oyaizu \& Komagata, 1981; R. J. Owen, unpublished results); for $F$. capsulatum, these were detected in the assimilation of various carbon compounds (Oyaizu \& Komagata, 1981).

A feature of the relationship between DNA hybridization and protein similarities evident from Fig. 4 was that strains with zero DNA homology showed a calculated protein pattern similarity of about $30 \%$. This characteristic was attributed to the best fit algorithm used in the protein analysis ${ }^{\circ}$ computation, which considers the highest similarity as the most appropriate. The value was similar to that found between completely unrelated bacterial groups and represents the inherent similarity in the general shape of electrophoretic patterns (Jackman, 1981). The fact that each peak may be a composite of several structurally and functionally different proteins with the same electrophoretic mobility, could contribute to this apparent high background similarity level.

Eleven of the $P$. paucimobilis strains were previously included by Holmes et al. (1977) in a numerical analysis of phenotypic characteristics. In the case of the strains with high levels of DNA similarity, there was an excellent agreement with similarities based on the phenetic analysis, but the linear congruence between the two approaches did not hold at lower levels of DNA relatedness. The data on these particular strains show that similarities derived from protein analysis are a more sensitive measure of taxonomic differences than those derived from phenetic analyses. Even so, the latter technique indicated that strains such as A97/68 and CL158/74 were atypical of $P$. paucimobilis, but there were no obvious reasons to argue for their exclusion from the new species (Holmes et al., 1977). Jones \& Sneath (1970) and Harvey \& Pickett (1980) recognized the lack of linearity between similarities based on DNA and phenetic analyses. Harvey \& Pickett (1980) concluded from their study of Yersinia enterocolitica that differences between the two approaches were due to the fact that DNA hybridization was based on the entire genome, whereas numerical phenetic analysis measured at best only $20 \%$ of the genome through phenotypic expression, and to problems in test reproducibility.

The generic and supra-generic affinities of $P$. paucimobilis are uncertain. There is strong evidence from rRNA cistron comparisons (Bauwens \& De Ley, 1981), cellular fatty acid profiles (Dees et al., 1979; Oyaizu \& Komagata, 1981) and numerical phenetic analysis (Holmes et al., 1977), that the species is not an authentic member of the genus Pseudomonas. On the basis of rRNA hybridization, Bauwens \& De Ley (1981) found that $F$. capsulatum was a member of an rRNA superfamily which contained members of the 'Acetobacteriaceae' (e.g. Acetobacter, Gluconobacter, Agrobacterium and Rhizobium) (Gillis \& De Ley, 1980). The species with the closest affinities to $F$. capsulatum were ' $P$. azotocolligans', 'C. folium', $P$. paucimobilis and $F$. 
devorans. There are additional chemotaxonomic data which point to the uniqueness of these bacteria: (a) Pseudomonas paucimobilis, ' $P$. azotocolligans' and $P$. echinoides contain a yellow pigment which Jenkins et al. (1979) identified as a nostoxanthin; hitherto this pigment was reported to occur only in a few species of cyanobacteria; (b) Pseudomonas paucimobilis and $F$. devorans contain a novel sphingoglycolipid (ceramide gluconuric acid) as a major component of the cellular lipids (Yabuuchi et al., 1979); (c) the major cellular fatty acid in $P$. paucimobilis, $F$. devorans and $F$. capsulatum is $\mathrm{C}_{18: 1}$, which represents at least $50 \%$ of the total fatty acid, as well as 2-OH-C $\mathrm{C}_{14: 0}, \mathrm{C}_{16: 0}, \mathrm{C}_{16: 1}, \mathrm{C}_{17: 1}$ acids (Dees et al., 1979; Yabuuchi et al., 1979; Oyaizu \& Komagata, 1981); and (d) the main respiratory quinones in $P$. paucimobilis and $F$. capsulatum are ubiquinones (Q-10) (Oyaizu \& Komagata, 1981).

These data and the DNA hybridization results obtained in the present study, which indicated a background similarity of $8-12 \%$ between $P$. paucimobilis, $F$. capsulatum, 'P. azotocolligans' and $P$. echinoides, show that these species may eventually justify inclusion in a new genus.

We thank Janis Dowling for technical assistance, and Dr L. R. Hill and Professor W. C. Noble for critical reading of the manuscript. P. J. H. Jackman thanks the Dunhill Trust for financial support.

\section{REFERENCES}

Bauwens, M. \& DE LEY, J. (1981). Improvements in the taxonomy of Flavobacterium by DNA :rRNA hybridizations. In The Flavobacterium-Cytophaga Group, pp. 27-31. Edited by H. Reichenbach \& O. B. Weeks. Weinheim: Verlag Chemie.

Crane, L. R., Tagle, L. C. \& Palutke, W. A. (1981). Outbreak of Pseudomonas paucimobilis in an intensive care facility. Journal of the American Medical Association 246, 985-987.

Crosa, J. H., Brenner, D. J. \& Falkow, S. (1973). Use of a single-strand specific nuclease for analysis of bacterial and plasmid deoxyribonucleic acid homo- and heteroduplexes. Journal of Bacteriology $115,904-911$.

Dees, S. B., Moss, C. W., Weaver, R. E. \& Hollis, D. (1979). Cellular fatty acid composition of Pseudomonas paucimobilis and Groups IIk-2, Ve-1 and Ve-2. Journal of Clinical Microbiology 10, 206-209.

De Ley, J., Segers, P. \& Gillis, M. (1978). Intra- and intergeneric similarities of Chromobacterium and Janthinobacterium ribosomal ribonucleic acid cistrons. International Journal of Systematic Bacteriology 38, 154-168.

GILLIS, M. \& DE LEY, J. (1980). Intra- and intergeneric similarities of the ribosomal ribonucleic acid cistrons of Acetobacter and Gluconobacter. International Journal of Systematic Bacteriology 30, 7-27.

Hajiroussou, V., Holmes, B., Bullas, J. \& Pinning, C. A. (1979). Meningitis caused by Pseudomonas paucimobilis. Journal of Clinical Pathology 32, 953955.

HaRvey, S. \& Pickett, M. J. (1980). Comparison of Adansonian analysis and deoxyribonucleic acid hybridization results in the taxonomy of Yersinia enterocolitica. International Journal of Systematic Bacteriology 30, 86-102.

Holmes, B., OWen, R. J., Evans, A., Malnick, H. \& WILCOX, W. R. (1977). Pseudomonas paucimobilis, a new species isolated from human clinical specimens, the hospital environment, and other sources. International Journal of Systematic Bacteriology 27, 133146.
Holmes, B., Owen, R. J. \& Weaver, R. E. (1981). Flavobacterium multivorum, a new species isolated from human clinical specimens and previously known as Group IIk, biotype 2. International Journal of Systematic Bacteriology 31, 21-34.

JACKMAN, P. J. H. (1981). Taxonomy of aerobic axillary coryneforms based on electrophoretic protein patterns, Ph.D. thesis, University of London, U.K

Jenkins, C. L., Andrewes, A. G., McQuade, T. J. \& Stark, M. P. (1979). The pigment of Pseudomonas paucimobilis is a carotenoid (nostoxanthin), rather than a brominated aryl-polyene (xanthomonadin). Current Microbiology 3, 1-4.

JoNES, D. \& SNEATH, P. H. A. (1970). Genetic transfer and bacterial taxonomy. Bacteriological Reviews 34, 40-81.

Kersters, K. \& DE LeY, J. (1980). Classification and identification of bacteria by electrophoresis of their proteins. In Microbiological Classification and Identification, SAB Symposium Series No. 8, pp. 273297. Edited by M. Goodfellow \& R. G. Board. London: Academic Press.

MARMuR, J. \& Doty, P. (1962). Determination of the base composition of deoxyribonucleic acid from its thermal denaturation temperature. Journal of Molecular Biology 5, 109-118.

OWEN, R. J. \& Holmes, B. (1978). Heterogeneity in the characteristics of deoxyribonucleic acid from Flavobacterium odoratum. FEMS Microbiology Letters 4, 41-46.

OWEN, R. J. \& Holmes, B. (1980). Differentiation between strains of Flavobacterium breve and allied bacteria by comparisons of deoxyribonucleic acids. Current Microbiology 4, 7-11.

OWEN, R. J. \& SNELl, J. J. S. (1976). Deoxyribonucleic acid reassociation in the classification of flavobacteria. Journal of General Microbiology 93, 89-102.

Owen, R. J., Legros, R. M. \& Lapage, S. P. (1978). Base composition, size and sequence similarities of genome deoxyribonucleic acids from clinical isolates of Pseudomonas putrefaciens. Journal of General Microbiology 104, 127-138. 
Oyaizu, H. \& Komagata, K. (1981). Chemotaxonomic and phenotypic characterization of the strains of species in the Flavobacterium-Cytophaga complex. Journal of General and Applied Microbiology 27, 57-107.

Peel, M. M., Davis, J. M., Armstrong, W. L. H., Wilson, J. R. \& Holmes, B. (1979). Pseudomonas paucimobilis from a leg ulcer on a Japanese seaman. Journal of Clinical Microbiology 9, 561-564.

Popoff, M. \& Coynault, C. (1980). Use of DEAEcellulose filters in the $S 1$ nuclease method for bacterial deoxyribonucleic acid hybridization. Annales de microbiologie 131A, 151-155.

SAlzberg, G., LeVi, Z., Aboud, M. \& Goldberger, A. (1977). Isolation and characterization of DNADNA and DNA-RNA hybrid molecules formed in solution. Biochemistry 16, 25-29.

Skerman, V. B. D., McGowan, V. \& Sneath, P. H. A. (1980). Approved lists of bacterial names. Interna- tional Journal of Systematic Bacteriology 30, 225-420.

Slotnick, I. J., Hall, J. \& Sacks, H. (1979). Septicaemia caused by Pseudomonas paucimobilis. American Journal of Clinical Pathology 72, 882-884.

SNEATH, P. H. A. \& Sokal, R. R. (1973). Numerical Taxonomy: The Principles and Practice of Numerical Classification. San Francisco: W. H. Freeman.

TATUM, H. W., EWING, W. H. \& Weaver, R. E. (1974). Miscellaneous Gram-negative bacteria. In Manual of Clinical Microbiology, 2ndiedn, pp. 270-294. Edited by E. H. Lennett, E. H. Spaulding \& J. P. Truant. Washington, D.C.: American Society for Microbiology.

YabuUchi, E., Tanimura, E., Ohyama, A., Yano, I. \& YамАМОТо, А. (1979). Flavobacterium devorans ATCC 10829: a strain of Pseudomonas paucimobilis. Journal of General and Applied Microbiology 25, 95107. 